\title{
MODEL PENYELESAIAN PERSELISIHAN PERKAWINAN PERSPEKTIF HUKUM ADAT DAN HUKUM ISLAM
}

\author{
Muhammad Habibi Miftakhul Marwa \\ Fakultas Hukum Universitas Ahmad Dahlan \\ habibi.marwa@law.uad.ac.id
}

\begin{abstract}
Abstrak
Tujuan penelitian ini untuk menganalisis konsep hukum perkawinan dan model penyelesaian perselisihan perkawinan untuk menghindari perceraian perspektif hukum adat dan hukum Islam. Prinsip utama dilakukan perkawinan adalah untuk mewujudkan kebahagiaan selama-lamanya bukan sementara. Perselisihan rumah tangga yang tidak segera diselesaikan menjadi salah satu pemicu terjadinya perceraian. Akibat perceraian akan menimbulkan problematika terhadap anak, harta selama perkawinan, dan status salah satu bekas suami-istri menjadi janda atau duda. Artikel ini secara spesifik fokus menganalisis bagaimana konsep perkawinan dan model penyelesaian perselisihan perkawinan menurut hukum adat dan hukum Islam. Metode penelitian yang digunakan adalah penelitian normatif dengan pendekatan perundang-undangan (statute approach) dan pendekatan perbandingan (comparative approach). Hasil penelitian ini adalah (1) Hukum perkawinan adat berpedoman pada pandangan hidup masyarakat adat yang dicerminkan pada sistem kekeluargaan yang berlaku dalam masyarakat tersebut. Sedangkan, pelaksanaan hukum perkawinan Islam berdasarkan sumber hukum Islam. Perkawinan dalam hukum adat dan hukum Islam dimaksudkan untuk mewujudkan keluarga yang bahagia dan kekal abadi. Setiap terjadi perselisihan perkawinan dianjurkan untuk segera diselesaikan supaya tidak mengganggu keharmonisan rumah tangga yang dapat mengakibatkan putusnya perkawinan. (2) Model penyelesaian perselisihan perkawinan dalam hukum adat dan hukum Islam diutamakan diselesaikan melalui musyawarah untuk mufakat. Mekanisme pelaksanaan musyawarah untuk damai dalam hukum adat dilakukan terlebih dahulu oleh para pihak yang berselisih dibantu keluarga. Apabila tidak berhasil dimintakan bantuan kepada tokoh adat dan kepala desa yang dianggap memilik kewenangan dan otoritas lebih dalam penyelesaian sengketa. Sedangkan model penyelesaian perselisihan perkawinan menurut hukum Islam ialah melalui musyawarah, mediasi dan mengangkat hakam.
\end{abstract}

Kata Kunci : Hukum Adat; Hukum Islam; Perkawinan

\section{MODEL OF MARRIAGE DISPUTE SETTLEMENT PERSPECTIVE OF TRADITIONAL LAW AND ISLAMIC LAW}

\begin{abstract}
The purpose of this study is to analyze the concept of marital law and the model of marital dispute settlement to avoid divorce from the perspective of customary law and Islamic law. The main principle of marriage is to realize happiness forever, not temporary. Domestic disputes that are not immediately resolved are one of the triggers for divorce. As a result of divorce, it will cause problems for children, property during marriage, and the status of one of the former husband and wife being a widow or widower. This article specifically focuses on analyzing the concept of marriage and the model for resolving marital disputes according to customary law and Islamic law. The research method used is normative research with a statute approach and a comparative approach. The results of this study are (1) customary marriage law is guided by the view of life of indigenous peoples which is reflected in the family system that applies in that society. Meanwhile, the implementation of Islamic marriage law is based on Islamic law sources. Marriage in customary law and Islamic law is intended to create a happy and eternal family. Every time there is a marital dispute, it is recommended that it be resolved immediately so as not to disturb the harmony of the household which can result in the dissolution of the marriage. (2) The marital dispute settlement model in customary law and Islamic law is prioritized to be resolved through deliberation for consensus. The mechanism for implementing deliberation for peace in customary law is carried out first by the disputing parties with the help of their families. If it does not work, ask for assistance from traditional leaders and village heads who are considered to have more authority and authority in resolving disputes. While the model of settlement of marital disputes according to Islamic law is through deliberation, mediation and lifting of judges.
\end{abstract}

Keywords : Customary Law; Islamic Law; Marriage 


\section{A. PENDAHULUAN}

Perkawinan merupakan ajaran yang bersifat universal. Beragam suku, agama, budaya, dan negara memiliki peraturan mengenai perkawinan. Sistem perkawinan di Indonesia sebelum Undang-Undang Nomor 1 Tahun 1974 tentang Perkawinan (disebut UU Perkawinan) bersifat pluralistik, karena memiliki beragam sistem hukum perkawinan, seperti sistem perkawinan adat, sistem perkawinan barat, sistem perkawinan Islam, dan sistem perkawinan menurut agama-agama resmi di Indonesia. Kondisi ini dipengaruhi kebijakan politik hukum Hindia Belanda dengan diberlakukan Pasal 131 IS (Indische Staatsregeling) tentang penggolongan pemberlakuan hukum untuk masingmasing golongan penduduk, dan Pasal 163 IS tentang penggolongan penduduk. Sistem hukum perkawinan di Indonesia bersifat unifikasi sejak diundangkan UU Perkawinan sebagai aturan induk atas keberagaman hukum perkawinan yang ada. ${ }^{1}$

Rumusan tujuan perkawinan dalam Pasal 1 Kompilasi Hukum Islam (KHI) maupun Pasal 1 UU Perkawinan menghendaki perkawinan dilangsungkan untuk mencapai kebahagiaan yang kekal selamanya. ${ }^{2}$ Sementara, hukum adat menganut prinsip perkawinannya sekali untuk dipertahankan selamanya atau sepisan sak lawase, sampai keken-kaken, ninen-ninen (sampai suami-istri menjadi kakek-kakek, nenek-nenek). ${ }^{3}$

Perkawinan sebagai perbuatan hukum menimbulkan sejumlah hak dan kewajiban antara suami-istri sejak dilangsungkan ijab-qabul. Pemenuhan hak dan kewajiban yang bersifat materiil maupun immaterial harus dilakukan secara adil dan makruf sehingga mampu mewujudkan rumah tangga yang bahagia secara permanent. ${ }^{4} \mathrm{Hak}$ dan kewajiban perkawinan apabila tidak ditunaikan dengan baik dapat menimbulkan perselisihan. Perselisihan kecil dalam rumah tangga menjadi salah satu sumber yang cukup signifikan terhadap meningkatnya angka perceraian. ${ }^{5}$ Data bulan Oktober 2019, 253 dari 483 kasus perceraian di Sidoarjo didominasi karena perselisihan dan pertengkaran yang terus menerus dalam keluarga. ${ }^{6}$

Penelitian Iqbal, dkk (2020), pola penyelesaian sengketa rumah tangga menurut hukum adat dapat dilakukan melalui peradilan adat dengan cara mediasi untuk mendamaikan para pihak yang berselisih. Penyelesaian perselisihan seperti melalui Peradilan Adat Gampong Aceh didasarkan pada spirit Islam. Tahapan penyelesaian melalui adat dimulai dengan tahapan pelaporan pokok perkara, penerimaan laporan oleh

\footnotetext{
${ }^{1}$ Sirman Dahwal, Perbandingan Hukum Perkawinan, I (Bandung: Mandar Maju, 2017). Hlm. 7

2 Undang-Undang Nomor 1 Tahun 1974 Tentang Perkawinan (Lembaran Negara Tahun 1975 Nomor 12, Tambahan Lembaran Negara Nomor 3050).

${ }^{3}$ A Suriyaman Masturi Pide, Hukum Adat: Dahulu, Kini, Dan Akan Datang (Edisi Pertama), I (Jakarta: Prenada Media Group, 2015).

${ }^{4}$ Syahrizal Abbas, Mediasi Dalam Hukum Syariah, Hukum Adat, Dan Hukum Nasional, ed. 2 (Jakarta: Prenada Media, 2011). Hlm. 180

5 "Https://Www.Suarasurabaya.Net/Kelanakota/2019/Sebagian-Besar-Perceraian-Disebabkan-PerselisihanKecil/," n.d. Diakses 1 Mei 2020

6“"Https://Radarsurabaya.Jawapos.Com/Read/2019/11/09/165158/Perselisihan-Jadi-Penyebab-UtamaPerceraian," n.d. Diakses 1 Mei 2020
} 
otoritas atau pemangku peradilan adat, persidangan, pembacaan putusan, dan pemberian sanksi. $^{7}$

Penyelesaian perselisihan pada masyarakat adat lebih mengedepankan musyawarah mufakat untuk damai, menjunjung tinggi nilai kebersamaan secara lahir-batin, dan menjaga kepentingan komunal dibanding individual. Hal ini dipertegas dalam penelitian Marpemsory (2017), bahwa penyelesaian perselisihan perkawinan melalui peradilan adat dilakukan penuh kekeluargaan, biaya ringan, hasilnya lebih efektif. ${ }^{8}$ Berbagai kelebihan menggunakan penyelesaian adat tersebut semata-mata mengembalikan hubungan keluarga supaya harmonis dan tujuan utama perkawinan dapat terwujud.

Menurut penelitian Listamin B, dkk (2018), beberapa faktor penyebab keretakan hubungan keluarga karena selingkuh, suami-istri tidak menunaikan hak dan kewajiban, pemabuk, penjudi, tidak menghargai orang tua, perbedaan derajat, dan suami atau istri meninggalkan rumah, mekanisme lain yang dapat digunakan dengan melibatkan tokoh adat dengan memberi nasehat kedua pasangan, melakukan pendekatan keluarga suamiistri, mendamaikan antar keluarga, sehingga hubungan keluarga menjadi harmonis kembali. ${ }^{9}$

Menyelesaikan sengketa melalui peradilan adat dan tokoh adat sebenarnya hanya bagian kecil saja dari konsep penyelesaian perselisihan dalam hukum adat. Mengingat masih ada mekanisme lain yang digunakan masyarakat sebelum diajukan ke Peradilan Adat seperti dimusyawarahkan terlebih dahulu oleh para pihak yang berselisih, melibatkan pihak keluarga, tokoh agama, tokoh masyarakat (adat), hingga menghadirkan pemerintah desa.

Selanjutnya, penelitian Djuaini (2016) membahas resolusi konflik nusyuz oleh suami-istri menurut hukum Islam. Nusyuz dapat dipahami sebagai kedurhakaan atau pertentangan dalam rumah tangga oleh suami kepada istri atau istri kepada suami yang menyebabkan retaknya hubungan keluarga. Hukum Islam memberikan solusi penyelesaian terhadap nusyuz istri, yaitu suami memberi nasihat, pisah ranjang, melakukan tindakan tegas yang mendidik, dan mengangkat hakam atau juru damai. ${ }^{10}$

Fokus kajian ini membandingkan model penyelesaian perselisihan perkawinan yang berlangsung terus-menerus yang dapat mengakibatkan putusnya perkawinan (perceraian). Keadaan semacam ini dalam hukum Islam disebut syiqaq. Jika penelitian sebelumnya fokus pada kasus nusyuz, sementara artikel ini mengambil kasus syiqaq yang merupakan perselisihan rumah tangga yang berlangsung lama dan sudah memuncak.

\footnotetext{
${ }^{7}$ Muhammad Iqbal, Azhari Yahya, and Husni Kamal, "Pola Penyelesaian Sengketa Dalam Rumah Tangga Melalui Peradilan Adat Gampong Di Aceh," Jurnal Geuthee: Penelitian Multidisiplin 3, no. 1 (2020): 383-93, https://doi.org/10.15797/concom.2019..23.009.

8 Marpemsory, "Penyelesaian Sengketa Perkawinan Melalui Peradilan Adat Di Kecamatan Tanjung Kemuning," Qiyas 2, no. 1 (2017): 83-95.

${ }^{9}$ Listamin, La Ode Monto, and Muh Asryad, "Konflik Perkawinan Dan Cara Penyelesaian Melalui Tokoh Adat (Studi Di Desa Labone Kecamatan Lasaalepa Kabupaten Muna)," Neo Society 3, no. 2 (2018): 362-73, https://doi.org/http://dx.doi.org/10.52423/jns.v3i2.4023.

${ }^{10}$ Djuaini Djuaini, "Konflik Nusyuz Dalam Relasi Suami-Istri Dan Resolusinya Perspektif Hukum Islam," Istinbath 15, no. 2 (2016): 255-80.
} 
Perceraian dalam masyarakat adat merupakan peristiwa luar biasa, karena perbuatan tersebut tidak disenangi masyarakat adat. ${ }^{11}$ Islam juga menyatakan bahwa perceraian adalah perbuatan halal yang dibenci Allah Swt. Dampak perceraian tidak hanya dirasakan pihak yang bercerai, tetapi juga terhadap anak, harta, bahkan terhadap keluarga besar kedua mempelai. Oleh karena itu, mempertahankan perkawinan yang mendatangkan kemaslahatan jauh lebih baik dari pada langsung menempuh jalur perceraian.

Penyelesaian perselisihan dalam hukum adat dan hukum Islam berangkat dari sebuah konsep perkawinan yang keduanya memiliki tempat pengaturan tersendiri. Keduanya harus dipahami secara proporsional dan komprehensif supaya menghasilkan pemahaman yang baik, karena sejatinya perkawinan dan bentuk penyelesaian perselisihan harus dilakukan dengan menjunjung tinggi nilai-nilai kemanusiaan, keadilan, persatuan, dan menempatkan manusia sebagai makhluk sosial yang bermartabat. Jika memahaminya secara parsial mengakibatkan seolah terjadi kontradiksi konsep penyelesaian sengketa perkawinan. Penelitian ini bertujuan membandingkan dan mendeskripsikan konsep perkawinan serta model penyelesaian perselisihan perkawinan perspektif hukum adat dan hukum Islam.

\section{B. PERMASALAHAN}

Berdasarkan pendahuluan di atas artikel ini mengambil dua permasalahan sebagai berikut:

1. Bagaimana konsep perkawinan perspektif hukum adat dan hukum Islam?

2. Bagaimana model penyelesaian perselisihan perkawinan perspektif hukum adat dan hukum Islam?

\section{METODE PENELITIAN}

Metode yang digunakan dalam penelitian ini adalah penelitian hukum normatif dengan menggunakan sumber data sekunder yang diperoleh dari hasil telaah pustaka yang relevan dengan masalah yang dibahas. ${ }^{12}$ Data sekunder yang terdiri dari sumber data primer seperti Undang-Undang Nomor 1 Tahun 1974 tentang Perkawinan diubah menjadi Undang-Undang Nomor 16 Tahun 2019 tentang Perubahan Atas Undang-Undang Nomor 1 Tahun 1974 tentang Perkawinan (disebut UU Perkawinan), Undang-Undang Nomor 30 Tahun 1999 tentang Arbitrase dan Alternatif Penyelesaian Sengketa, Peraturan Mahkamah Agung Nomor 1 Tahun 2016 tentang Prosedur Mediasi di Pengadilan, dan Instruksi Presiden Nomor 1 Tahun 1991 tentang Penyebarluasan Kompilasi Hukum Islam. Sementara, data sekunder berupa buku, jurnal, dan hasil penelitian. Data yang terkumpul dianalisis secara deskriptif kualitatif menggunakan pendekatan perundangundangan (statute approach) dan pendekatan perbandingan (comparative approach), yaitu antara hukum adat dan hukum Islam dalam penyelesaian perselisihan perkawinan.

\footnotetext{
${ }^{11}$ P.N.H. Simanjuntak, Hukum Perdata Indonesia, 2nd ed. (Jakarta: Prenadamedia Group, 2016). Hlm. 142

${ }^{12}$ Mukti Fajar Nur Dewata and Yulianto Achmad, Dualisme Penelitian Hukum Normatif \& Empiris, I (Jakarta: Pustaka Pelajar, 2010). Hlm. 154
} 


\section{HASIL DAN PEMBAHASAN}

\section{Konsep Perkawinan Perspektif Hukum Hukum Adat dan Hukum Islam \\ 1.1. Konsep Perkawinan Perspektif Hukum Adat}

Hukum adat sebagai aspek kebudayaan oleh masyarakat dijadikan pedoman hidup bagi masyarakat setempat. Hukum adat diformulasikan sebagai aturan yang dibentuk tanpa melalui badan legislatif, pemberlakuannya mempertimbangkan kondisi psikologi masyarakat tanpa menghilangkan rasa keadilan, dan diberlakukan sanksi adat. Menurut Pide, ruang lingkup ilmu pengetahuan hukum adat dibagi menjadi tiga kelompok, yaitu hukum adat ketatanegaraan, hukum adat kewargaan, dan hukum adat delik (pelanggaran). Di antara bagian dari pada hukum adat kewargaan adalah hukum perkawinan adat yang mengatur tentang bentuk-bentuk perkawinan adat, cara pelamaran, upacara perkawinan, dan putusnya perkawinan. ${ }^{13}$ Dari definisi tersebut, dapat dipahami bahwa perkawinan adat mengatur rangkaian perkawinan berdasarkan hukum adat setempat guna mempertahankan nilai-nilai luhur yang telah berlangsung secara turun-temurun.

Adanya perbedaan aturan hukum perkawinan yang ada di Indonesia karena beragam adat istiadat, agama dan kepercayaan masing-masing yang sangat plural. Perkawinan adat diselenggarakan untuk menentukan sistem kekeluargaan yang didasarkan pada garis keturunan. Secara garis besar sistem masyarakat adat di Indonesia didasarkan pada sistem keturunan yang terbagi menjadi tiga sistem, yaitu sistem patrilineal (garis bapak), matrilineal (garis ibu), dan parental atau bilateral (garis bapakibu). ${ }^{14}$

Mengingat susunan masyarakat di Indonesia yang berbeda-beda berdampak terhadap model perkawinan adat, seperti perkawinan semenda, perkawinan bebas, perkawinan lari, perkawinan jujur, dan perkawinan campuran. Masih berlakunya berbagai macam pernikahan adat tersebut, karena UU Perkawinan belum mengatur ketentuan seperti bentuk perkawinan, cara peminangan atau lamaran, upacara perkawinan, dan lain sebagainya. Selama praktik perkawinan adat belum diatur dan tidak melanggar hukum positif, berarti masyarakat diperbolehkan melaksanakan perkawinan adat yang berlaku di Indonesia. Perkawinan dalam hukum adat bukan hanya persoalan mempelai laki-laki dan perempuan (suami-istri) saja, tetapi menyangkut kepentingan keluarga dan masyarakat.

Perkawinan adat merupakan satu peristiwa yang dilakukan oleh individu dapat berdampak terhadap kepentingan orang banyak. Perkawinan diusahakan untuk tetap dipertahankan guna meraih kebahagiaan keluarga sekaligus meneruskan tata nilai yang dijunjung tinggi masyarakat adat. Adanya perbedaan sistem kekerabatan masyarakat adat menjadikan tujuan perkawinan juga didasarkan pada sistem yang dianut keluarga tersebut. Masyarakat yang menganut sistem patrilineal maka perkawinannya mempunyai tujuan bagaimana mempertahankan garis keturunan dari bapak. Begitu juga sistem kekerabatan yang menarik garis ibu (matrilineal), maupun ibu dan bapak (parental), sama-

\footnotetext{
${ }^{13}$ Pide, Hukum Adat : Dahulu, Kini, Dan Akan Datang (Edisi Pertama). Hlm. 20-22

${ }^{14}$ Dahwal, Perbandingan Hukum Perkawinan. Hlm. 4-6
} 
sama menghendaki supaya sistem kekerabatannya tetap dipertahankan dalam perkawinan. $^{15}$

Masyarakat adat menganggap perceraian sebagai problem sosial-kemasyarakatan yang merupakan peristiwa luar biasa sehingga harus dihindari. ${ }^{16}$ Perkawinan dalam konstruksi hukum adat dilangsungkan sekali dan dipertahankan untuk selama-lamanya, meskipun dalam kenyataan sehari-hari perkawinan yang diusahakan untuk dipertahankan berakhir perceraian dengan berbagai macam alasan. Prinsip mempertahankan perkawinan didasarkan pada sistem kekerabatan masing-masing masyarakat adat. Termasuk bentuk pertanggungjawaban setelah putusnya perkawinan. Pada masyarakat yang bersifat patrilineal, terjadinya perceraian tidak mengubah tanggungjawab kerabat pihak suami terhadap orang yang ditinggal mati. Begitu juga dalam masyarakat matrilineal, bahwa pertanggungjawaban tetap berada di pihak ibu terhadap yang ditinggalnya, meskipun dapat diambil alih pihak keluarga suami manakala pihak ibu tidak memiliki kemampuan. Dalam masyarakat parental atau bilateral, pertanggungjawaban mengurus dan memelihara yang ditinggalnya berada di pihak keluarga suami atau keluarga istri, tergantung keadaan dan kemampuan yang bersangkutan.

\subsection{Konsep Perkawinan Perspektif Hukum Perkawinan Islam}

Perkawinan dalam bahasa Arab berasal dari kata al-nikah bermakna bersetubuh, berkumpul, dan akad. ${ }^{17}$ Perkawinan berhubungan erat dengan akad atau perjanjian antara laki-laki dan perempuan sehingga terikat dalam ikatan perkawinan sah. Sejak dilangsungkan akad nikah kedua mempelai yang awalnya haram bersetubuh menjadi halal. Keduanya kemudian dapat berkumpul dan membangun keluarga (rumah tangga) yang bahagia dan abadi. Istilah hukum perkawinan Islam dalam khasanah hukum Islam disebut fiqh munakahat yang berarti seperangkat aturan yang bersifat amaliah furu'iyah berdasarkan wahyu ilahi yang mengatur hal ihwal perkawinan yang berlaku untuk seluruh umat yang beragama Islam. ${ }^{18}$

Pasal 2 KHI memberikan definisi perkawinan menurut hukum Islam adalah pernikahan, yaitu akad yang sangat kuat atau miitsaaqan ghaliidzan untuk mentaati perintah Allah dan melaksanakannya merupakan ibadah. Rumusan "akad yang sangat kuat atau miitsaaqan ghaliidzan" dalam UU Perkawinan bermakna sebagai ikatan lahirbatin. Artinya, perkawinan tidak hanya berdimensi keperdataan melainkan juga bersifat transendensi (ibadah). Kemudian "untuk mentaati perintah Allah dan melaksanakannya merupakan ibadah" sebagaimana UU Perkawinan adalah penjelasan Ketuhanan Yang Maha Esa. Bagi seorang muslim melangsungkan perkawinan bukan saja berdimensi dunia melainkan peristiwa agama yang sakral yang berdampak terhadap kehidupan akhirat, bahkan menjadi bagian dari ibadah bagi yang mengerjakan. ${ }^{19}$

\footnotetext{
${ }^{15}$ Pide, Hukum Adat : Dahulu, Kini, Dan Akan Datang (Edisi Pertama). Hlm. 23

${ }^{16}$ Simanjuntak, Hukum Perdata Indonesia. Hlm. 142

${ }^{17}$ Anwar Rachman, Prawitra Thalib, and Saepudin Muhtar, Hukum Perkawinan Indonesia Dalam Perspektif Hukum Perdata, Hukum Islam, Dan Hukum Administrasi, I (Jakarta: Prenadamedia Group, 2020).Rachman, Thalib, and Muhtar.

${ }^{18}$ Amir Syarifuddin, Hukum Perkawinan Islam Di Indonesia : Antara Fiqh Munakahat Dan Undang-Undang Perkawinan, 2nd ed. (Jakarta: Prenada Media, 2007). Hlm. 1-5

${ }^{19}$ Instruksi Presiden Nomor 1 Tahun 1991 Tentang Penyebarluasan Kompilasi Hukum Islam.
} 
Substansi Pasal 2 KHI menegaskan filosofis perkawinan Islam, tanpa mereduksi landasan filosofi UU Perkawinan. ${ }^{20}$ Landasan filosofis perkawinan Islam menyatakan perkawinan untuk mentaati perintah Allah Swt, menunaikan perkawinan sebagai ibadah, dan perkawinan merupakan ikatan yang sangat kuat atau miitsaqan ghaliidzan. Tujuan perkawinan Islam telah dinyatakan Pasal 3 KHI, yaitu mewujudkan kehidupan rumah tangga yang sakinah (tenang, tentram dan bahagia), mawaddah (rasa cinta yang bersifat jasmani), dan rahmah (kasih sayang bersifat rohani), yaitu keluarga yang diliputi rasa saling cinta-mencintai dan rasa kasih sayang antara sesama keluarga. ${ }^{21}$

Perkawinan sebagai ibadah harus memenuhi rukun dan syarat sebagaimana ibadah lainnya. Rukun perkawinan merupakan hal yang harus dipenuhi pada saat perkawinan dilangsungkan, sedangkan syarat perkawinan merupakan hal yang harus dipenuhi sebelum dan pada saat perkawinan itu dilangsungkan. Secara garis besar, unsur pokok atau rukun perkawinan yaitu calon laki-laki, calon perempuan, wali nikah, dua orang saksi, dan ijab yang dilakukan oleh wali, serta qabul yang dilakukan oleh mempelai lakilaki. ${ }^{22}$ Sementara syarat perkawinan adalah syarat yang berkaitan dengan rukun-rukun perkawinan, yaitu syarat-syarat yang harus dipenuhi dari masing-masing rukun perkawinan. Terpenuhinya rukun dan syarat perkawinan menjadikan perkawinan tersebut sah, begitu juga sebaliknya rukun dan syarat yang tidak terpenuhi menyebabkan pernikahan menjadi tidak sah.

Hukum perkawinan menegaskan asas perkawinan dilangsungkan untuk selamalamanya atau asas mempersulit terjadinya perceraian. ${ }^{23}$ Maksudnya, pelaksanaan perkawinan yang dilakukan mempelai laki-laki dan perempuan idealnya untuk menggapai kebahagiaan yang bersifat kekal selamanya. Islam menetapkan bahwa akad nikah diselenggarakan secara suci, kokoh, dan berlangsung untuk selamanya antara suami-istri. Hal ini sejalan dengan Firman Allah Swt., :

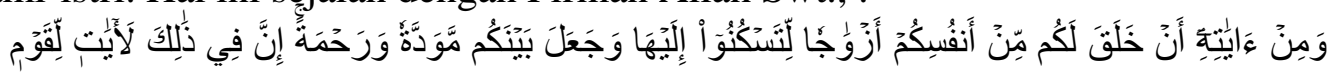

Artinya: Dan di antara tanda-tanda (kebesaran)-Nya ialah Dia menciptakan pasangan-pasangan untukmu dari jenismu sendiri, agar kamu cenderung dan merasa tenteram kepadanya, dan Dia menjadikan di antaramu rasa kasih dan sayang. (Ar-Rum: 21).

Al Quran memang tidak secara tegas menganjurkan atau melarang perceraian. Hal ini berbeda dengan anjuran untuk melaksanakan perkawinan yang setidaknya terdapat 85 ayat di antara 600 ayat, dan tersebar dalam 22 surat dari 114 surat dalam Al Quran. Namun, Al Quran hanya mengatur manakala perceraian harus terjadi, maka harus dilakukan dengan baik. ${ }^{24}$ Menurut hukum Islam, perkawinan putus dapat dibenarkan

${ }^{20}$ Abd Shomad, Hukum Islam : Penormaan Prinsip Syariah Dalam Hukum Indonesia, 1st ed. (Jakarta: Kencana Prenada Media Group, 2010). Hlm. 275-277

${ }^{21}$ Instruksi Presiden Nomor 1 Tahun 1991 tentang Penyebarluasan Kompilasi Hukum Islam.

${ }^{22}$ Syarifuddin, Hukum Perkawinan Islam Di Indonesia: Antara Fiqh Munakahat Dan Undang-Undang Perkawinan. Hlm. 59-61

${ }^{23}$ Djuaini, "Konflik Nusyuz Dalam Relasi Suami-Istri Dan Resolusinya Perspektif Hukum Islam."

${ }^{24}$ Syarifuddin, Hukum Perkawinan Islam Di Indonesia: Antara Fiqh Munakahat Dan Undang-Undang Perkawinan. Hlm. 200 
apabila tidak dapat dihindari lagi. Namun, dalam pelaksanaan perceraian jangan sampai dilakukan secara sewenang-wenang. Ketentuan perceraian hanya boleh dilangsungkan ketika keduanya dalam keadaan yang dibenarkan sebagaimana diterangkan dalam surat At-Talaq ayat 1.

Perceraian merupakan suatu hal yang halal, namun dihukumi makhruh (dibenci) Allah Swt. Sebagaimana hadist dari Ibnu Umar bahwa Nabi Muhammad Saw :

أَبْغَضُ الْحَلَالِ إِلَى اللَّهِ تَعَالَى الطَّلََق

Artinya : Perbuatan halal yang paling dibenci Allah adalah talaq. (HR. Abu Daud, Ibnu Majah, dan Al-Hakim)

Madzhab Hanafiah dan Madzhab Hanbali, mengatakan bahwa perceraian terlarang atau tidak dibolehkan kecuali darurat. Alasannya adalah Sabda Nabi Muhammad Saw : “ Allah melaknat tiap-tiap orang yang suka merasai dan bercerai.". Hadist tersebut merupakan peringatan kepada umat manusia supaya jangan terlalu mudah menceraikan seorang istri. Islam menempatkan perceraian ibarat "pintu darurat" hanya digunakan apabila sangat mendesak dan darurat serta dapat membahayakan diri dan keluarga. ${ }^{25}$

Oleh karena itu, perceraian harus dipahami sebagai solusi terakhir setelah berbagai upaya telah ditempuh oleh suami-istri untuk mempertahankan keutuhan rumah tangga. Maksud solusi akhir berarti telah dilakukan berbagai upaya untuk berdamai, baik melalui mediasi maupun pengangkatan hakam dari kedua belah pihak sebagaimana diajarkan syariat. Sehingga, berdasarkan tujuan dan asas perkawinan, perkawinan harus dilangsungkan dan diusahakan untuk seumur hidup sampai salah satu meninggal dunia, di mana perceraian hanya menjadi jalan terakhir.

\section{Model Penyelesaian Perselisihan Perkawinan Perspektif Hukum Adat Dan Hukum Islam}

\subsection{Model Penyelesaian Perselisihan Perkawinan Perspektif Hukum Adat}

Guna memelihara sebuah keluarga yang harmonis pada masyarakat tertentu di Indonesia, maka dibentuk hukum adat untuk mengatur model penyelesaian apabila terjadi perselisihan perkawinan. ${ }^{26}$ Masyarakat adat bercorak tradisional, keagamaan, kebersamaan, konkret dan visual, terbuka dan sederhana, dapat berubah dan menyesuaikan, tidak dikodifikasi, musyawarah, dan mufakat. ${ }^{27}$ Setiap terjadi perselisihan mekanisme penyelesaiannya disesuaikan dengan corak adat. Penyelesaian sengketa adat dimaksudkan mewujudkan hidup damai permanent bagi seluruh masyarakat dengan pendekatan persuasif sesuai adat masing-masing. Supaya tidak menimbulkan guncangan terhadap kehidupan sosial kemasyarakatan yang berkepanjangan, ketika terjadi perselisihan maka harus segera diselesaikan sesuai hukum adat yang berlaku. Dengan diselesaikan secara cepat dan tepat diharapkan keseimbangan masyarakat kembali pulih seperti semula.

25 U.T. Wijayanti, "Analisis Faktor Penyebab Perceraian Pada Masa Pandemi Covid-19 Di Kabupaten Banyumas," Jurnal Ilmu Keluarga Dan Konsumen 14, no. 1 (2021): 14-26, https://doi.org/https://doi.org/10.24156/jikk.2021.14.1.14.

${ }^{26}$ Listamin, Monto, and Asryad, "Konflik Perkawinan Dan Cara Penyelesaian Melalui Tokoh Adat (Studi Di Desa Labone Kecamatan Lasaalepa Kabupaten Muna)."

${ }^{27}$ Pide, Hukum Adat : Dahulu, Kini, Dan Akan Datang (Edisi Pertama). Hlm. 26 
Masyarakat adat memiliki tradisi penyelesaian sengketa yaitu berpegang pada filosofi kebersamaan, pengorbanan, nilai supernatural, dan keadilan. ${ }^{28}$ Penerapan prinsip kebersamaan diwujudkan dalam segala aspek kehidupan guna mencapai keharmonisan di masyarakat. Ini merupakan implementasi eksistensi manusia sebagai makhluk sosial (komunal) bukan makhluk individual. Setiap terjadi perselisihan yang dapat mengganggu kepentingan komunal, maka harus diselesaikan secara adat yang biasanya disertai upacara-upacara ritual (supernatural).

Prinsip kebersamaan yang dipegangi masyarakat adat dalam menyelesaikan perselisihan memiliki konsekuensi, yaitu para pihak harus bersedia mengorbankan kepentingan pribadi demi kepentingan bersama. ${ }^{29}$ Menjunjung tinggi nilai-nilai luhur yang berkembang dan dipertahankan dalam masyarakat adat merupakan kepentingan bersama yang harus ditempatkan di atas kepentingan pribadi. Apabila terdapat anggota masyarakat yang tidak bersedia mengorbankan kepentingan dirinya untuk mewujudkan kepentingan bersama (adat), orang tersebut akan dinilai negatif oleh adat setempat, karena dianggap berani melawan nilai-nilai adat yang dipegangi masyarakat.

Penyelesaian sengketa adat ditentukan oleh nilai-nilai hukum adat, tokoh adat, dan kelembagaan adat. $^{30}$ Nilai-nilai hukum adat merupakan kaidah atau norma yang dipedomani masyarakat adat dalam berperilaku. Baik dan buruknya perilaku seseorang di masyarakat dapat dilihat dan dinilai dari pengamalan nilai-nilai adat tersebut. Seseorang dikatakan baik jika mampu mentaati dan menjaga nilai-nilai adat, begitu juga sebaliknya. Oleh karena itu, nilai-nilai adat oleh tokoh adat dijadikan pedoman dalam menjalankan tugas menyelesaikan perselisihan di masyarakat.

Tokoh adat merupakan sosok yang memiliki kharisma dan pemahaman hukum adat yang diperolehnya secara turun-menurun dari leluhurnya. Mereka yang bertindak sebagai penegak terhadap nilai-nilai adat apabila ada yang melanggarnya. Termasuk yang dijadikan pemimpin yang dituakan oleh masyarakat dalam penyelesaian sengketa. Sedangkan kelembagaan adat ialah institusi yang memiliki fungsi untuk menjaga dan mempertahankan hukum adat dalam masyarakat. Melalui kelembagaan adat inilah tokoh adat memiliki legitimasi yang kuat dalam menjalankan kewenangan untuk merawat dan menjaga nilai-nilai adat yang berlaku di masyarakat.

Selain itu masyarakat hukum adat dalam menyelesaikan perselisihan didasarkan pada filosofi dan corak masyarakat hukum adat itu sendiri, yaitu melalui jalur musyawarah dan mufakat. Jalur ini yang diutamakan dalam menyelesaikan sengketa, karena penyelesaiannya dibuat berdasarkan kesepakatan damai oleh kedua belah pihak tanpa ada yang merasa dirugikan guna mewujudkan kedamaian bagi keseluruhan masyarakat adat. Inilah bentuk kepentingan bersama (komunal) yang dijunjung tinggi dalam masyarakat adat. Penggunaan musyawarah untuk menyelesaikan sengketa bukan berarti meniadakan peran dan proses penyelesaian perselisihan melalui peradilan adat.

${ }^{28}$ Abbas, Mediasi Dalam Hukum Syariah, Hukum Adat, Dan Hukum Nasional. Hlm. 243

${ }^{29}$ Listamin, Monto, and Asryad, "Konflik Perkawinan Dan Cara Penyelesaian Melalui Tokoh Adat (Studi Di Desa Labone Kecamatan Lasaalepa Kabupaten Muna).”

${ }^{30}$ Listamin, Monto, and Asryad. 
Penyelesaian sengketa melalui musyawarah maupun peradilan adat, tetap dijalankan menggunakan pendekatan musyawarah untuk mufakat.

Mekanisme penyelesaian perselisihan perkawinan pada masyarakat adat secara musyawarah dapat dilakukan oleh beberapa pihak. Pertama. Penyelesaian antara pribadi, keluarga, dan tetangga. Guna mengembalikan keseimbangan keluarga dan sosial kemasyarakatan, apabila terjadi perselisihan perkawinan yang dialami anggota masyarakat adat, maka terlebih dahulu diselesaikan oleh pribadi yang bersangkutan. Kedua belah pihak yang berselisih diminta berdamai untuk menyelesaikan perselisihannya sebelum minta bantuan kepada pihak lain. Apabila perselisihan tersebut tidak dapat diselesaikan oleh para pihak yang bersangkutan, dilanjutkan dengan mengadakan pertemuan antara keluarga para pihak yang berselisih dengan tujuan utama mengadakan perundingan untuk damai. Dalam sengketa perkawinan, guna menjaga aib keluarga biasanya pihak yang pertama kali membantu para pihak yang berselisih adalah orang tua atau kerabat dari kedua belah pihak. Karena sejatinya perkawinan dalam masyarakat adat bukan saja urusan pasangan suami-istri belaka, tetapi membawa kepentingan seluruh keluarga besar bahkan masyarakat adat ikut berkepentingan. Ketika terjadi perselisihan keluarga dan masyarakat adat ikut tanggung jawab, karena itu bagian dari kepentingan komunal. Para pihak yang berselisih juga dapat meminta bantuan kepada tetangga yang dianggap memiliki kemampuan mendamaikan. Manakala pribadi yang bersangkutan, tetangga, dan keluarga kedua pihak tidak mampu menyelesaikan perselisihan, maka diperlukan bantuan dari yang lebih tinggi tingkat otoritasnya, yaitu minta bantuan tokoh adat dari kedua pihak.

Kedua. Penyelesaian tokoh adat atau kepala adat. Mengingat dalam perkawinan adat juga menyangkut urusan kerabat, keluarga, dan masyarakat adat, ketika terjadi perselisihan keluarga yang dapat mengganggu kepentingan bersama, maka penyelesaiannya dapat dilanjutkan kepada tokoh adat atau kepala adat. Mereka dihormati, diyakini dapat menjaga rahasia dan memiliki kemampuan menyelesaikan sengketa, sehingga dipercaya pihak yang berselisih untuk terlibat mendamaikan. Tokoh adat memiliki kewenangan menyelesaikan perkara berkaitan dengan nilai-nilai adat khususnya yang bersifat kekerabatan. Mereka sebagai penjaga stabilitas adat dan berkewajiban menyelesaikan sengketa. Model penyelesaian perselisihan termasuk dalam perkawinan dilakukan melalui mekanisme hukum adat yang diperankan oleh tokoh adat dalam bentuk mediasi, negosiasi, fasilitasi, dan arbitrase. Tokoh adat kemudian akan melangsungkan pertemuan atau musyawarah untuk mufakat guna menyelesaikan perselisihan. Penyelesaian yang ditempuh para pihak yang berselisih dilakukan secara kekeluargaan dengan berbagai bentuk penyelesaian guna mencari jalan keluar yang terbaik untuk rukun dan berdamai dengan dibantu oleh tokoh adat sebagai mediator, negosiator, fasilitator, dan arbiter. ${ }^{31}$

${ }^{31}$ Nur Intan, "Peran Pemuka Adat Sebagai Mediator Terhdap Penyelesaian Konflik Dalam Proses Perkawinan Pada Masyarakat Muna Di Sulawesi Tenggara," Melayunesia Law 2, no. 1 (2018): 1-10, https://doi.org/http://dx.doi.org/10.30652/ml.v2i1.5491. 
Ketiga. Penyelesaian kepala desa. Penyelesaian perselisihan di masyarakat yang dilakukan kepala desa berkaitan dengan ketetanggaan masyarakat secara umum, bukan yang bersifat khusus berdasarkan pertalian kekerabatan, seperti perkawinan. Namun, kepala desa atas permohonan warga masyarakat dapat terlibat dalam membantu menyelesaikan sengketa yang bersifat kekerabatan. Model penyelesaian yang dilakukan kepala desa sama seperti yang dilakukan tokoh adat yaitu berusaha mewujudkan kerukunan dan kedamaian melalui musyawarah antara dua pihak yang berselisih untuk mengembalikan keseimbangan sosial di masyarakat. Bahkan dalam hal-hal tertentu, antara kepala desa dengan tokoh adat umumnya bekerjasama sama untuk menyelesaikan perselisihan sehingga terwujud kesepakatan, kedamaian, dan kerukunan antara mereka yang berselisih. Tokoh adat bersama aparatur desa bersama masyarakat membuat kesepakatan mufakat, sedangkan sanksi yang ditetapkan harus ditaati pelanggar adat khususnya dan seluruh masyarakat pada umumnya. ${ }^{32}$

\subsection{Model Penyelesaian Perselisihan Perkawinan Perspektif Hukum Perkawinan Islam}

Islam menghendaki perkawinan itu dilakukan untuk waktu selama-lamanya. Namun, dalam keadaan tertentu jika perkawinan tetap dilangsungkan justru akan membawa mudarat, Islam memberikan jalan keluar dengan putusnya perkawinan sebagai jalan terakhir dari usaha melanjutkan rumah tangga. Maka, penting dilakukan beberapa usaha guna menghadapi perselisihan rumah tangga agar bahtera keluarga tetap terjaga.

Al Quran paling tidak memberikan tiga petunjuk untuk mengantisipasi terjadinya putusnya perkawinan, yaitu nusyuz istri, nusyuz suami, dan syiqaq. Cara menghadapi nusyuz istri (kedurhakaan istri terhadap suami), sebagaimana dalam surat An-Nisa: 34, dilakukan dengan memberi peringatan dan pengajaran oleh suami kepada istrinya, pisah tempat tidur, dan memukul istri dengan pukulan yang mengandung edukasi bukan menyakiti. Nusyuz suami (kedurhakaan suami kepada istri karena meninggalkan kewajiban terhadap istrinya) cara mengatasinya telah dijelaskan dalam surat An-Nisa: 128, yaitu dengan melakukan perdamaian (shulh) yang menyelesaikan masalah. Perdamaian yang dimaksud adalah perundingan yang membawa kebaikan bersama supaya tidak terjadi perceraian. Syiqaq (pertengkaran hebat suami-istri) yang tidak dapat diselesaikan sendiri oleh keduanya, maka mekanisme menyelesaikannya sebagaimana surat An-Nisa:35, yaitu dengan mengutus juru damai (hakam). Penyelesaian perselisihan perkawinan dalam hukum Islam baik di pengadilan atau di luar pengadilan dilakukan dengan musyawarah, mediasi, dan pengangkatan hakam.

1. Musyawarah

Konsep musyawarah dalam Islam merupakan landasan atas ditegakkannya prinsip kesamaan hak dan kewajiban dalam kehidupan manusia. Musyawarah untuk mufakat termasuk ajaran Islam yang selalu Allah Swt ingatkan kepada umat muslim ketika

${ }^{32}$ Pide, Hukum Adat : Dahulu, Kini, Dan Akan Datang (Edisi Pertama). 
menghadapi dan menyelesaikan masalah. ${ }^{33}$ Prinsip menyelesaikan persoalan keluarga melalui musyawarah menghendaki proses dialogis antara para pihak yang berkonflik. Perintah musyawarah dalam Islam tertuang dalam firman Allah Swt, :

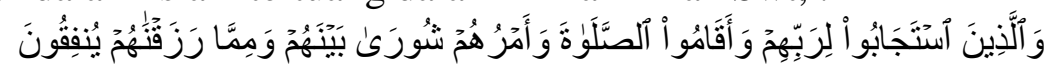

Artinya : Dan (bagi) orang-orang yang menerima (mematuhi) seruan Tuhannya dan mendirikan shalat, sedang urusan mereka (diputuskan) dengan musyawarah antara mereka, dan mereka menafkahkan sebagian dari rizeki yang kami berikan kepada mereka. (Q.S. Asy-Syura : 38).

Pelaksanaan musyawarah hendaknya dilakukan dengan penuh hikmah, arif, dan bijaksana, sehingga menghasilkan keputusan yang menghadirkan kemaslahatan bagi semuanya. Dengan dilakukannya penyelesaian melalui musyawarah diharapkan tetap terjalin persaudaraan dan kekeluargaan antara para pihak yang berselisih serta lebih dapat menjaga hubungan yang baik di antara para pihak. Ketika penyelesaian perselisihan melalui musyawarah tidak tercapai baru kemudian para pihak dapat menempuh upaya melalui jalur mediasi.

\section{Mediasi}

Mediasi merupakan salah satu bentuk penyelesaian sengketa melalui perundingan dengan melibatkan pihak ketiga yang bersikap netral (non intervensi) dan tidak berpihak (impartial) serta kehadirannya diterima oleh pihak-pihak yang bersengketa. ${ }^{34}$ Mediator sebagai pihak ketiga yang dilibatkan dalam mediasi bertugas memfasilitasi yang bersengketa untuk mencari penyelesaian. Mediasi dipandang mampu memberikan jalan keluar atas permasalahan yang dihadapi para pihak yang berselisih karena pendekatan yang digunakan adalah musyawarah mufakat untuk mencari win-win solution.

Mediasi awalnya dikenal dalam praktek penyelesaian sengketa bisnis ${ }^{35}$, meskipun dalam perkembangannya diterapkan dalam hukum keluarga. Istilah "tidak ada mediasi tanpa negosiasi" memang sering dikembangkan dalam tradisi mediasi bisnis dengan bargaining position di mana masing-masing pihak mempertahankan kepentingannya. ${ }^{36}$ Namun, mengedepankan posisi tawar dalam penyelesaian perselisihan perkawinan (perceraian) kurang tepat untuk diterapkan, karena yang terjadi bukan menyelesaikan masalah tetapi justru menambah masalah. Oleh karena itu, dalam proses mediasi persoalan keluarga mediator harus mampu menyeimbangkan posisi tawar antara pihak laki-laki dan perempuan supaya sejajar. Mediasi untuk mengembalikan keharmonisan keluarga seharusnya tidak ada siapa yang memiliki posisi kuat atau lemah, tetapi harus diposisikan setara atau sejajar. Karena fungsi mediasi dalam hukum keluarga supaya tidak

\footnotetext{
${ }^{33}$ Musyfikah Ilyas, "Tinjauan Hukum Islam Terhadap Musyawarah Dalam Penyelesaian Sengketa Ekonomi Syariah," Jurnal Al-Qadau:Peradilan Dan Hukum Keluarga Islam 5, no. 2 (2018): 227-36, https://doi.org/https://doi.org/10.24252/al-qadau.v5i2.7104.

${ }^{34}$ Neni Sri Imaniyati and Panji Adam Agus Putra, Hukum Bisnis Dilengkapi Dengan Kaajian Hukum Bisnis Syariah (Bandung: PT. Refika Aditama, 2017). Hlm. 394

${ }^{35}$ Imaniyati and Putra. Hlm. 394

${ }^{36}$ Dedi Sumanto and Syamsinah, "Mediasi Dan Hakam Dalam Hukum Acara Peradilan Agama," Al-Mizan 11, no. 1 (2015): 152-62.
} 
terjadi perceraian, maka mediator harus berusaha menerapkan sama-sama menang bukan menang atau kalah.

Perdamaian akan membawa kemanfaatan besar bagi para pihak yang berselisih dalam persoalan rumah tangga. Oleh karena itu, berbagai upaya perdamaian harus terus dilakukan secara optimal supaya tidak terjadi perceraian. ${ }^{37}$ Kewajiban mendamaikan para pihak yang berselisih juga bagian ajaran Islam. Allah Swt berfirman:

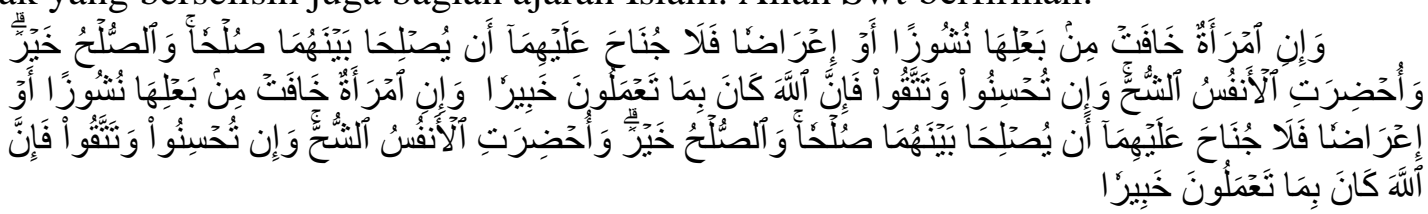

Artinya : Dan jika seorang wanita khawatir akan nusyuz atau sikap tidak acuh dari suaminya, maka tidak mengapa bagi keduanya mengadakan perdamaian yang sebenarbenarnya, dan perdamaian itu lebih baik (bagi mereka) walaupun manusia itu menurut tabiatnya kikir. Dan jika kamu bergaul dengan isterimu secara baik dan memelihara dirimu (dari nusyuz dan sikap tak acuh), maka sesungguhnya Allah adalah Maha Mengetahui apa yang kamu kerjakan. (Q.S. An-Nisa : 128).

Mediasi dalam hukum Islam sepadan dengan at-tahkîm (tahkim) yang berarti kesepakatan para pihak yang bersengketa untuk menyerahkan putusan sengketa tersebut kepada pihak ketiga (hakam). ${ }^{38}$ Pelaksanaan damai dalam Islam menggunakan musyawarah agar segera ditemukan jalan keluar atas perselisihannya, termasuk jika memilih menggunakan jalur mediasi. ${ }^{39}$

Mediasi dalam sistem hukum Indonesia didasarkan pada Peraturan Mahkamah Agung (PERMA) Nomor 1 Tahun 2016 tentang Prosedur Mediasi di Pengadilan menyebutkan bahwa mediasi merupakan bagian dari hukum acara dalam perkara perdata. ${ }^{40}$ Meski posisinya tidak dapat dibandingkan dengan undang-undang, PERMA merupakan kemajuan dari Undang-Undang Nomor 30 tahun 1999 tentang Arbitrase dan Alternatif Penyelesaian Sengketa yang menganggap mediasi sebagai alternatif penyelesaian sengketa. ${ }^{41}$

Terhadap perkara perceraian hakim harus mengusahakan mediasi para pihak yang berselisih untuk berdamai supaya tidak cerai. Perintah melakukan mediasi untuk perkara perdata bersifat imperatif atau compulsory. Pihak yang berselisih wajib mengikuti proses mediasi dengan difasilitasi mediator. Bahkan proses litigasi dilarang dilanjutkan ke tahap berikutnya sebelum ada pernyataan tertulis mediator yang menyatakan proses mediasi gagal mencapai kesepakatan damai. ${ }^{42}$ Sebagaimana Pasal 3 PERMA No.1/2016 bahwa

${ }^{37}$ Arne Huzaimah, "Urgensi Integrasi Antara Mediasi Dan Hakam Dalam Penyelesaian Perkara Perceraian Dengan Alasan Syiqaq Di Pengadilan Agama," Nurani 16, no. 2 (2016): 1-24, https://doi.org/https://doi.org/10.19109/nurani.v16i2.931.

${ }^{38}$ Ahmed Shoim El-Amin, "Konsep Mediasi Dalam Hukum Islam,” Al-Munqidz: Jurnal Kajian Keislaman 2, no. 1 (2013): 21-30, https://doi.org/https://doi.org/10.52802/amk.v2i2.32.

${ }^{39}$ H M Umar, "Hukum Islam: Telaah Perkara Perceraian Melalui Proses Mediasi," Jurnal Literasuiologi 4, no. 2 (2020): 175-86.

${ }^{40}$ Peraturan Mahkamah Agung Nomor 1 Tahun 2016 Tentang Prosedur Mediasi Di Pengadilan.

${ }^{41}$ Undang-Undang Nomor 30 Tahun 1999 Tentang Arbitrase Dan Alternatif Penyelesaian Sengketa (Lembaran Negara Tahun 1999 Nomor 138, Tambahan Lembaran Negara Nomor 3872).

${ }^{42}$ M. Yahya Harahap, Hukum Acara Perdata : Gugatan, Persidangan, Penyitaan, Pembuktian, Dan Putusan Pengadilan, Keempat (Jakarta: Sinar Grafika, 2006). Hlm. 250 
hakim yang menangani perkara tetapi tidak memerintahkan para pihak untuk mediasi, berarti melanggar peraturan perundang-undangan. Mengingat mediasi bagian dari syarat formil dalam proses acara di pengadilan, jika terdapat putusan hakim yang tidak menempuh mediasi dapat dinyatakan batal demi hukum.

Secara keseluruhan mediasi dibagi menjadi tiga tahap yaitu tahap pra mediasi, tahap pelaksanaan mediasi, dan tahap pelaksanaan hasil mediasi. Tahap pra mediasi dilakukan hakim dengan menghadirkan para pihak. Tahap pelaksanaan mediasi dilakukan oleh mediator dan para pihak untuk merumuskan bersama proses perdamaian. Tahap pelaksanaan yaitu hasil mediasi ditandatangani para pihak dan mediator kemudian dilaporkan kepada hakim. Jika mediasi akan dikeluarkan akta perdamaian, tetapi jika tidak berhasil sidang dilanjutkan kepada pokok perkara. ${ }^{43}$ Kesepakatan dari mediasi sama seperti sebuah perjanjian yang dibuat oleh para pihak sehingga memiliki daya ikat yang kuat. Keberhasilan mencapai perdamaian kemudian dituangkan dalam akta perdamaian dan para pihak terikat untuk mentaati isi kesepakatan. Sebagaimana Pasal 130 ayat (2) HIR bahwa akta perdamaian dapat mengakhiri perkara antara para pihak dan berlaku sebagai putusan hakim yang mempunyai kekuatan hukum tetap (in kracht van gewijsde).

Proses mediasi dalam konteks penyelesaian perselisihan perkawinan memiliki kedudukan sangat penting guna mencegah terjadinya perceraian. Mediasi dapat dijadikan cara untuk mengembalikan hubungan suami-istri agar tercapai kebahagiaan selamanya, sehingga terwujud bangunan keluarga sakinah, Mawaddah, dan rahmah.

\section{Pengangkatan Hakam}

Manakala terjadi perselisihan suami-istri yang meruncing dan dikhawatirkan menimbulkan kehancuran rumah tangga, menghadirkan pihak ketiga sebagai hakam merupakan sebuah solusi untuk menyelesaikan perselisihan tersebut. Perselisihan rumah tangga yang sangat hebat dalam institusi hukum Islam diistilahkan syiqaq. Hal ini didasarkan firman Allah Swt, :

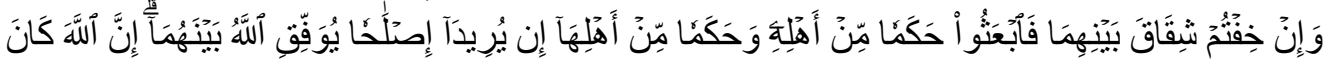

$$
\begin{aligned}
& \text { عَلِيمًا خَبيرًا }
\end{aligned}
$$

Artinya : Dan jika kamu khawatirkan ada persengketaan (syiqaq) antara keduanya, maka kirimlah seorang hakam dari keluarga laki-laki dan seorang hakam dari keluarga perempuan. Jika kedua orang hakam itu bermaksud mengadakan perbaikan niscaya Allah memberi taufik kepada suami-istri itu. Sesungguhnya Allah Maha Mengetahui lagi Maha Mengenal. (Q.S. An-Nisa: 35).

Hakam dihadirkan sebagai juru damai guna menyelesaikan perselisihan rumah tangga yang tajam supaya kembali hidup rukun dan damai. Maka rumusannya menjadi, apabila terjadi perselisihan yang hebat suami-istri (syiqaq), maka diutus penengah (hakam) yang bertugas mendamaikan (ishlah) para pihak yang berselisih.

Menurut Pasal 76 ayat 2 Undang-Undang Nomor 7 Tahun 1989 Peradilan Agama, hakam adalah orang yang ditetapkan pengadilan dari pihak keluarga suami atau pihak keluarga istri atau pihak lain untuk mencari upaya penyelesaian terhadap syiqaq." Para

43 Febri Handayani and Syafliwar, "Implementasi Mediasi Dalam Penyelesaian Perkara Perceraian Di Pengadilan Agama,” Jurnal Al-Himayah 1, no. 2 (2017): 227-50. 
ulama memiliki pendapat yang berbeda dalam menentukan posisi orang yang diangkat sebagai hakam. Kelompok pertama mengklaim bahwa hakam diambil dari keluarga sebagai wakil suami-istri dengan alasan kehormatan istri adalah milik suami dan sebaliknya kehormatan suami milik istri. Kelompok kedua menyatakan kedudukan hakam sebagai hakim agar dapat mengambil tindakan yang terbaik untuk kepentingan suami-istri yang sedang berselisih. ${ }^{44}$

Menurut Yahya Harahap ${ }^{45}$, berdasarkan ciri dan kewenangannya, hakam dalam khasanah hukum Islam disamakan dengan arbitrator (arbiter). Ciri keduanya dapat dilihat dari cara penyelesaian sengketa dilakukan secara sukarela, dilakukan di luar peradilan yang resmi, para pihak menunjuk hakam/arbiter. Mahkamah arbitrase berwenang penuh menyelesaikan sengketa dengan cara menjatuhkan putusan dan sifat putusan final dan mengikat. Kewenangan yang demikian itu kelihatannya merujuk pada konsep hakam yang berasal dari institusi pengadilan sebagai hakim, bukan dari pihak keluarga yang tidak diberikan wewenang untuk memberikan putusan. Karena hasil keterangan yang disampaikan para hakam di persidangan akan dijadikan pertimbangan dalam putusan hakim. Hakam yang diangkat dan ditunjuk oleh hakim dipilih dari keluarga dengan diberi tugas dan kewenangan. ${ }^{46}$ Mereka bertugas melakukan usaha penyelidikan dan mendamaikan kembali suami-istri. Apabila terjadi dead lock, maka hakam diberi kekuasaan untuk melakukan tindakan lebih jauh dari perdamaian, namun tidak sampai menjatuhkan talak (suami menceraikan kepada istri) atau khulu' (istri menggugat cerai suami), karena yang berhak menjatuhkan putusan hanya hakam dari hakim.

Pengangkatan hakam dari keluarga suami-istri secara jelas dan tegas dinyatakan dalam surat An-Nisa : 35. Latar belakangnya karena keluarga sebagai kerabat dekat dianggap lebih mengetahui dan memahami kasus posisi yang sedang berselisih. Suami dan istri juga cenderung lebih terbuka untuk mengungkapkan permasalahan keluarga yang sedang dialami di hadapan keluarga sendiri dari pada kepada orang lain. Sekaligus untuk menjaga kerahasiaan keluarga. Namun, apabila tidak ada hakam yang dapat diangkat dari keluarga dapat diangkat dari luar tanpa mengesampingkan faktor keluarga.

Penyelesaian perselisihan perkawinan menggunakan hakam dilakukan setelah proses pembuktian, yaitu setelah hakim mendengar keterangan para pihak dari keluarga dan dituangkan dalam putusan sela. ${ }^{47}$ Hal ini menunjukkan kalau pengangkatan hakam bagian dari hukum penyelesaian perselisihan perkawinan di pengadilan dengan alasan syiqaq. Hasil musyawarah yang dilakukan hakam dalam proses mendamaikan pihak yang berselisih kemudian diserahkan ke pengadilan untuk dijadikan dasar hukum majelis hakim membuat putusan. Dengan demikian, hakam yang diambil dari keluarga tidak

${ }^{44}$ Syarifuddin, Hukum Perkawinan Islam Di Indonesia : Antara Fiqh Munakahat Dan Undang-Undang Perkawinan. Hlm. 196 Hlm. 320

${ }^{45}$ Harahap, Hukum Acara Perdata : Gugatan, Persidangan, Penyitaan, Pembuktian, Dan Putusan Pengadilan.

46 Dedi Mulyadi, "Peran Dan Fungsi Hakam Dalam Perkawinan Upaya Menanggulangi Syiqaq : Analisis Hukum Islam Dan Perundang-Undangan Di Indonesia,” Bil Dalil (Jurnal Hukum Keluarga Islam) 1, no. 2 (2016): 2947, https://doi.org/http://dx.doi.org/10.32678/bildalil.v1i02.122.

${ }^{47}$ Sumanto and Syamsinah, "Mediasi Dan Hakam Dalam Hukum Acara Peradilan Agama." 
memiliki kuasa menjatuhkan putusan yang mengikat selain hanya sebatas mendamaikan saja.

Menurut Huzaimah, praktik pengangkatan hakam dalam perkara perceraiannya dengan alasan syiqaq dianggap berbelit-belit, karena telah diadakan proses mediasi sebelum tahap pemeriksaan perkara. Mediasi dan hakam secara substansi sama yaitu mengupayakan perdamaian di antara para pihak. Supaya tidak dianggap bertentangan dengan asas hukum acara perdata yaitu asas sederhana, cepat, dan berbiaya ringan, maka diperlukan integrasi mediasi dan hakam untuk menyelesaikan perselisihan perkawinan karena alasan syiqaq. ${ }^{48}$ Sementara Sumanto, menawarkan alternatif untuk memberlakukan salah satu saja. Apabila memakai mediasi, maka prosesnya harus mengakomodir nilai-nilai yang terkandung dalam hakam. Namun, manakala yang ditempuh adalah jalur hakam, maka proses hakam dianggap bagian mediasi. ${ }^{49}$

Proses mediasi dan hakam dalam penyelesaian sengketa rumah tangga di pengadilan karena alasan syiqaq tetap harus ditempuh semuanya. Dua proses perdamaian perkawinan tersebut sebagai upaya mengembalikan kehidupan keluarga yang rukun dan damai. Paradigma yang digunakan dalam melihat upaya perdamaian tersebut bukan semata efektif atau tidak efektif, melainkan secara normatif perkawinan dalam Islam menganjurkan untuk menempuh berbagai langkah untuk mencari jalan keluar agar perkawinan tetap bertahan sehingga tujuan perkawinan dapat terwujud.

Berdasarkan penjelasan model penyelesaian perselisihan perkawinan di atas, semakin jelas bahwa Allah Swt menghendaki adanya usaha supaya tidak terjadi perceraian antara suami-istri. Namun, jika tidak ditemukan kemungkinan lain dengan segenap usaha yang ada, maka perceraian dapat ditempuh sebagai alternatif terakhir.

\section{E. PENUTUP}

Konsep perkawinan hukum adat didasarkan sistem kekeluargaan masyarakat yang berpijak pada sistem keturunan dengan prinsip nikah sekali untuk selamanya. Model penyelesaian perselisihan perkawinan pada hukum adat menggunakan musyawarah mufakat yang merupakan filosofi dan corak masyarakat adat untuk mengembalikan nilainilai adat demi terwujudnya kepentingan komunal yang dilakukan para pihak yang berselisih, keluarga atau kerabat, tokoh adat, dan kepala desa. Sedangkan konsep hukum perkawinan Islam mengajarkan perkawinan dimaksudkan membentuk keluarga sakinah, mawaddah, dan rahmah berdasarkan Ketuhanan Yang Maha Esa. Perceraian dalam hukum Islam sebagai alternatif terakhir ketika segala usaha untuk mengembalikan keharmonisan rumah tangga mengalami kegagalan. Model penyelesaian perselisihan perkawinan menurut hukum Islam dilakukan melalui musyawarah, mediasi, dan mengangkat hakam.

\footnotetext{
${ }^{48}$ Huzaimah, "Urgensi Integrasi Antara Mediasi Dan Hakam Dalam Penyelesaian Perkara Perceraian Dengan Alasan Syiqaq Di Pengadilan Agama."

${ }^{49}$ Sumanto and Syamsinah, "Mediasi Dan Hakam Dalam Hukum Acara Peradilan Agama."
} 


\section{DAFTAR PUSTAKA}

Abbas, Syahrizal. Mediasi Dalam Hukum Syariah, Hukum Adat, Dan Hukum Nasional. Edited by 2. Jakarta: Prenada Media, 2011.

Dahwal, Sirman. Perbandingan Hukum Perkawinan. I. Bandung: Mandar Maju, 2017.

Dewata, Mukti Fajar Nur, and Yulianto Achmad. Dualisme Penelitian Hukum Normatif \& Empiris. I. Jakarta: Pustaka Pelajar, 2010.

Djuaini, Djuaini. "Konflik Nusyuz Dalam Relasi Suami-Istri Dan Resolusinya Perspektif Hukum Islam." Istinbath 15, no. 2 (2016): 255-80.

El-Amin, Ahmed Shoim. "Konsep Mediasi Dalam Hukum Islam.” Al-Munqidz: Jurnal $\begin{array}{lllll}\text { Kajian Keislaman } & 2, \quad \text { no. } & 1 & \text { (2013): }\end{array}$ https://doi.org/https://doi.org/10.52802/amk.v2i2.32.

Handayani, Febri, and Syafliwar. "Implementasi Mediasi Dalam Penyelesaian Perkara Perceraian Di Pengadilan Agama.” Jurnal Al-Himayah 1, no. 2 (2017): 227-50.

Harahap, M. Yahya. Hukum Acara Perdata: Gugatan, Persidangan, Penyitaan, Pembuktian, Dan Putusan Pengadilan. Keempat. Jakarta: Sinar Grafika, 2006.

"Https://Radarsurabaya.Jawapos.Com/Read/2019/11/09/165158/Perselisihan-JadiPenyebab-Utama-Perceraian," n.d.

"Https://Www.Suarasurabaya.Net/Kelanakota/2019/Sebagian-Besar-PerceraianDisebabkan-Perselisihan-Kecil/," n.d.

Huzaimah, Arne. "Urgensi Integrasi Antara Mediasi Dan Hakam Dalam Penyelesaian Perkara Perceraian Dengan Alasan Syiqaq Di Pengadilan Agama." Nurani 16, no. 2 (2016): 1-24. https://doi.org/https://doi.org/10.19109/nurani.v16i2.931.

Ilyas, Musyfikah. "Tinjauan Hukum Islam Terhadap Musyawarah Dalam Penyelesaian Sengketa Ekonomi Syariah." Jurnal Al-Qadau :Peradilan Dan Hukum Keluarga Islam 5, no. 2 (2018): 227-36. https://doi.org/https://doi.org/10.24252/alqadau.v5i2.7104.

Imaniyati, Neni Sri, and Panji Adam Agus Putra. Hukum Bisnis Dilengkapi Dengan Kaajian Hukum Bisnis Syariah. Bandung: PT. Refika Aditama, 2017.

Instruksi Presiden Nomor 1 Tahun 1991 tentang Penyebarluasan Kompilasi Hukum Islam (n.d.).

Intan, Nur. "Peran Pemuka Adat Sebagai Mediator Terhdap Penyelesaian Konflik Dalam Proses Perkawinan Pada Masyarakat Muna Di Sulawesi Tenggara." Melayunesia Law 2, no. 1 (2018): 1-10. https://doi.org/http://dx.doi.org/10.30652/ml.v2i1.5491. Iqbal, Muhammad, Azhari Yahya, and Husni Kamal. "Pola Penyelesaian Sengketa Dalam Rumah Tangga Melalui Peradilan Adat Gampong Di Aceh." Jurnal Geuthee: Penelitian Multidisiplin 3, no. 1 (2020): 383-93. https://doi.org/10.15797/concom.2019..23.009.

Listamin, La Ode Monto, and Muh Asryad. "Konflik Perkawinan Dan Cara Penyelesaian Melalui Tokoh Adat (Studi Di Desa Labone Kecamatan Lasaalepa Kabupaten Muna)." Neo Society 3, no. 2 (2018): $362-73$. https://doi.org/http://dx.doi.org/10.52423/jns.v3i2.4023.

Marpemsory. "Penyelesaian Sengketa Perkawinan Melalui Peradilan Adat Di Kecamatan Tanjung Kemuning." Qiyas 2, no. 1 (2017): 83-95.

Mulyadi, Dedi. "Peran Dan Fungsi Hakam Dalam Perkawinan Upaya Menanggulangi Syiqaq : Analisis Hukum Islam Dan Perundang-Undangan Di Indonesia.” Bil Dalil 
(Jurnal Hukum Keluarga Islam) 1, no. 2 (2016): 29-47. https://doi.org/http://dx.doi.org/10.32678/bildalil.v1i02.122.

Peraturan Mahkamah Agung Nomor 1 Tahun 2016 tentang Prosedur Mediasi di Pengadilan (n.d.).

Pide, A Suriyaman Masturi. Hukum Adat: Dahulu, Kini, Dan Akan Datang (Edisi Pertama). I. Jakarta: Prenada Media Group, 2015.

Rachman, Anwar, Prawitra Thalib, and Saepudin Muhtar. Hukum Perkawinan Indonesia Dalam Perspektif Hukum Perdata, Hukum Islam, Dan Hukum Administrasi. I. Jakarta: Prenadamedia Group, 2020.

Shomad, Abd. Hukum Islam : Penormaan Prinsip Syariah Dalam Hukum Indonesia. 1st ed. Jakarta: Kencana Prenada Media Group, 2010.

Simanjuntak, P.N.H. Hukum Perdata Indonesia. 2nd ed. Jakarta: Prenadamedia Group, 2016.

Sumanto, Dedi, and Syamsinah. "Mediasi Dan Hakam Dalam Hukum Acara Peradilan Agama." Al-Mizan 11, no. 1 (2015): 152-62.

Syarifuddin, Amir. Hukum Perkawinan Islam Di Indonesia: Antara Fiqh Munakahat Dan Undang-Undang Perkawinan. 2nd ed. Jakarta: Prenada Media, 2007.

Umar, H M. "Hukum Islam: Telaah Perkara Perceraian Melalui Proses Mediasi." Jurnal Literasuiologi 4, no. 2 (2020): 175-86.

Undang-Undang Nomor 1 Tahun 1974 tentang Perkawinan (Lembaran Negara Tahun 1975 Nomor 12, Tambahan Lembaran Negara Nomor 3050) (n.d.).

Undang-Undang Nomor 30 Tahun 1999 tentang Arbitrase dan Alternatif Penyelesaian Sengketa (Lembaran Negara Tahun 1999 Nomor 138, Tambahan Lembaran Negara Nomor 3872) (n.d.).

Wijayanti, U.T. “Analisis Faktor Penyebab Perceraian Pada Masa Pandemi Covid-19 Di Kabupaten Banyumas.” Jurnal Ilmu Keluarga Dan Konsumen 14, no. 1 (2021): 1426. https://doi.org/https://doi.org/10.24156/jikk.2021.14.1.14. 